\title{
Kritik af forestillingen om et godt liv
}

\author{
Naturalisme, pragmatisme og kristen etik
}

\author{
Postdoc, ph.d. \\ René Rosfort
}

\begin{abstract}
This article examines the complex relation between naturalism, ethics, and ideas of a good life, in order to argue for the relevance of a Christian ethics in an age of naturalism. The first two sections deal with the question of naturalism. While strict naturalism maintains a view of nature based on the meaninglessness of nature, relaxed naturalism advocates a more pragmatic view of nature that allows for human meaning and practice. I argue that a relaxed form of naturalism is highly problematic due to its pragmatic emphasis. I also argue that a pragmatic naturalism is not able to answer two basic ethical demands, namely the demand of universalism and the demand of freedom. In the third and final section I sketch my view of a Christian ethics that is able to answer these demands. This ethics takes the form of a critique of our ideas of a good life, arguing that living ethically is a constant struggle both against and for the fragile character of human freedom. It is a radical ethics about the difficult work of human freedom for a hope of humanity that has no solid foundation and no clear answers.
\end{abstract}

Key Words: Naturalism - Pragmatism - Idea of a Good Life - Ethics Christian Ethics

In the tenderest spots of human experience, nothing is more offensive than intellectualized understanding. ${ }^{1}$

Forestillinger om et godt liv er slørede, usammenhængende og ofte modsætningsfyldte, og alligevel er sådanne forestillinger afgørende for de fleste menneskers eksistentielle kompas. Vores forestillinger om et godt liv bestemmer naturligvis ikke alle vores handlinger, men de rører sig mere eller mindre artikulerede i baggrunden af vores tanker og følelser og danner til tider et eksplicit orienteringspunkt for tilværelsens betydningsfulde afgørelser og valg. Det andet menneske

1. Christian Wiman, My Bright Abyss: Meditations of a Modern Believer (New York: Farrar, Straus and Giroux 2013), 19. 
spiller en grundlæggende rolle i disse forestillinger. De færreste mennesker er i stand til at forestille sig et godt liv uden andre mennesker. Det andet menneske er dog også et problem, eftersom den største udfordring til vores forestillinger om et godt liv er det andet menneskes frihed. Friheden til at forestille sig et godt liv er uløseligt forbundet med det at være menneske, og hvordan vi varetager denne frihed, vores egen såvel som det andet menneskes, betinger vores mulighed for at leve et godt liv. Etik er blandt andet et forsøg på at afklare mulighedsbetingelser og normative retningslinjer for en forestilling om et godt liv, der muliggør et fælles liv på baggrund af den menneskelige friheds individuelle udtryk.

I denne artikel vil jeg se på, hvilken betydning en kristen etik kan have for vores forestillinger om et godt liv i en tid, hvor en stadig mere udbredt naturalistisk forståelse af natur og menneske forekommer at have umuliggjort en sådan etik. Naturalisme kommer i mange former og afskygninger, og det kan være vanskeligt at danne sig et klart indtryk af, hvad det vil sige at være og leve som naturalist. De forskellige udgaver af naturalisme deler dog den grundlæggende overbevisning, at naturen på afgørende vis er bestemmende for et menneskes følelser, tanker og handlinger. Begrebet natur er rigtignok i sig selv flertydigt, og jeg vil i det følgende forsøge at vise, at en afklaring af naturbegrebet er afgørende for at forstå betydningen af naturalistiske udfordringer til en kristen etik. Jeg anser ikke naturalisme som et muligt fravalg i vores forestillinger om et godt liv. Jeg forstår dog heller ikke naturalisme som et problem for en kristen etik. Jeg vil tværtimod argumentere for, at naturalistiske overvejelser kan vise, hvorfor en kristen etik er vigtig for vores forestilling om et godt liv i dag. Jeg udfolder dette argument i tre trin. Jeg bruger de første to afsnit på spørgsmålet om naturalisme. Det første afsnit skitserer en central filosofisk debat om naturalisme. Denne debat handler netop om karakteren af et naturalistisk naturbegreb, hvor de såkaldte strenge naturalister argumenterer for en ren naturvidenskabelig forståelse af naturen ubesmittet af menneskelige behov og bekymringer, mens de mere afslappede naturalister forsøger at vise, at naturen er væsentlig mere menneskelig, end vi finder den afsløret gennem naturvidenskabens metoder og resultater. På baggrund af denne diskussion bruger jeg det andet afsnit til at kritisere de to former for naturalisme $i$ et forsøg på at afklare min egen naturalistiske position i forhold til spørgsmålet om vores forestillinger om et godt liv. Det er en position, der anerkender den strenge naturalismes naturbegreb uden dog at følge de strenge naturalister i deres ihærdige forsøg på at reducere etikken til deres naturopfattelse. Den strenge naturalismes umenneskelige naturbegreb viser netop, at vores forsøg på at grundlægge en etik på naturen strander på den selv samme natur. Jeg argumenterer 
for, at dette bliver tydeligt i den afslappede naturalismes erklærede pragmatisme. De afslappede naturalisters pragmatiske forestillinger om et godt liv fordrejer ikke blot den naturvidenskabelige forståelse af naturen i en sådan grad, at den diskvalificerer sig selv som en naturalistisk position, men tegner også et etisk problematisk billede af, hvad det vil sige at leve et godt liv. I det tredje afsnit forklarer jeg så, hvordan det umenneskelige naturbegreb i min udgave af den strenge form for naturalisme kan danne baggrund for udarbejdelsen af en kristen etik, der bygger på den radikale arv fra Kants og Kierkegaards arbejde med frihed, etik og naturforståelse.

\section{To former for naturalisme}

Der er udbredt enighed om, at det er svært at få styr på begrebet naturalisme. ${ }^{2}$ Der er mange forskellige naturalistiske programerklæringer med varierende ideologisk eftertryk, som vanskeliggør en klar forståelse af, hvad det indebærer at kalde sig naturalist. En generel - og ikke problemfri - beskrivelse af naturalisme er, at den er et forsøg på at etablere et solidt naturvidenskabeligt fortolkningsgrundlag for vores forstålse af verden og menneskets plads i denne verden. Det er først og fremmest vigtigt at skelne mellem naturvidenskab og naturalisme. Naturvidenskabelige discipliner som biologi, matematik, fysik, kemi og geologi udforsker forskellige aspekter af naturen og er som sådan specifikke praksisser, der er lokale i deres omfang og kun undtagelsesvis beskæftiger sig med globale spørgsmål som livets mening eller menneskets natur. Naturalisme er derimod en mere grundlæggende form for virkelighedsanskuelse, der går på tværs af de forskellige videnskaber, og den kan som nævnt anses som en global ambition om at skabe et solidt naturvidenskabeligt fortolkningsgrundlag for vores forståelse af verden, mennesket, de menneskelige værdier og livets mening. Videnskabsfilosoffen John Dupré beskriver elegant både naturalismens grundlæggende program og vanskeligheden ved at gennemføre et sådant program:

2. For gode introduktioner til - og kritisk diskussion af - den filosofiske debat om naturalisme, se antologierne Mario de Caro og David MacArthur (red.), Naturalism in Question (Cambridge, Mass.: Harvard University Press 2004) og Mario de Caro og David MacArthur (red.), Naturalism and Normativity (New York: Columbia University Press 2010). En grundig, men vanskelig gennemgang af naturalisme er også at finde på netportalen The Stanford Encyclopedia of Philosophy: David Papineau, "Naturalism", The Stanford Encyclopedia of Philosophy (Spring 2009 Edition), red. Edward N. Zalta (URL: http://plato.stanford.edu/archives/spr2009/entries/ naturalism/). 
A good start for understanding naturalism is the idea that in describing the world we should appeal to Nature rather than, for instance, Pure Reason or the interpretation of Holy Writ. Of course, appealing to Nature isn't such an easy matter. We can't just ask her, because she doesn't speak. Perhaps Francis Bacon was nearer to the mark when he suggested that we needed to torture her. ${ }^{3}$

Naturalisme er med andre ord ikke et deskriptivt foretagende, men et program med en stærk normativ fordring til vores forstålse af verden og mennesket.

Selv om debatten om naturalisme er blusset op over de sidste tyve år, er det en misforståelse at anse naturalistiske overvejelser for et nyt fænomen. Filosoffer og teologer har til alle tider kæmpet med en forståelse af naturen, og siden den videnskabelige revolution i det syttende århundrede har udforskning af naturen spillet en afgørende rolle for de fleste teorier om verden og mennesket. Med Darwin og den evolutionære revolution i anden halvdel af det nittende århundrede blev naturovervejelser et uomgængeligt element i teoridannelse, og efterfølgende teologisk og filosofisk arbejde har i stor udstrækning været et forsøg på at forholde sig til den voksende forståelse af naturen. Det er de færreste tænkere, selv i de tørreste af de tørre fag, der i dag betvivler, at mennesket er en biologisk organisme, hvis liv er formet - til en vis grad bestemt - af fysiske betingelser og biologiske værdier.

Naturalistiske overvejelser har med andre ord vejet tungt i filosofiske og teologiske undersøgelser af mennesket siden Darwin. Det er ambitionsniveauet, der adskiller tidligere tiders debat om naturalisme fra den aktuelle. Over de sidste halvtreds år er naturvidenskabelige discipliner som genetik, evolutionærbiologi og hjerneforskning begyndt at sammenstykke et menneskesyn på baggrund af deres empiriske forskningsresultater. Dette billede er endnu fragmenteret, men præsenteres med besnærende illustrationer af bevægelige kromosomer og DNA-strenge, farvestrålende (computergenererede) billeder af den levende hjerne og ikke mindst fantasifulde fortællinger om de oprindelige mennesker, der varmede sig om bålet i de palæolitiske nætter for godt 50.000 år siden. Spørgsmålet i den aktuelle debat om naturalisme drejer sig ikke om naturalismens berettigelse som fortolkningsbaggrund, men snarere om i hvilken grad vi kan trække på det naturvidenskabelige naturbegreb i vores forsøg på at besvare åbne filosofiske spørgsmål om menneskets natur og i vores forståelse af etiske problemer.

3. John Dupré, "How to be Naturalistic without being Simplistic in the Study of Human Nature”, de Caro og MacArthur (2010), 289-303 (289). 
Den aktuelle debat foregår mellem to stålsatte lejre. Den ene lejr de føromtalte strenge naturalister - argumenterer for et ubesmykket (bald) eller strengt naturalistisk naturbegreb, hvor naturvidenskabelige billeder og fortællinger trækkes utilsløret frem i forgrunden af vores forståelse af mennesket og menneskelige værdier. Den anden lejr argumenterer for en mere afslappet (relaxed) eller liberal naturalisme, der giver plads til historiske, kulturelle og personlige lag mellem den naturvidenskabelige baggrund og vores forsøg på at forstå menneskelige problemer og etiske udfordringer. ${ }^{4}$ Begge former for naturalisme afviser supernaturalistiske forklaringer ( $\mathrm{fx}$ transcendente guder eller platoniske idéer) og argumenterer for en kontinuerlig (dvs. monistisk og ikke dualistisk) forbindelse mellem menneske og natur. Den afgørende forskel på de to er at finde i deres syn på den natur, hvoraf mennesket er en uløselig del. Det er grundlæggende et spørgsmål om radikalitet. De strenge naturalister argumenterer for en radikalt naturvidenskabelig forstålse, mens de afslappede naturalister insisterer på en mere filosofisk moderat og menneskelig brug af de naturvidenskabelige resultater. Hvor de afslappede naturalister forsøger at forme deres grundlæggende naturforståelse efter menneskets mærkværdige natur, argumenterer de strenge naturalister for, at menneskets drømme, håb og forestillinger blot er et farverigt og skrøbeligt overfladespil på evolutionens mørke hav. Det er med andre ord grundlæggende et spørgsmål om vores forståelse af naturen. De strenge naturalister argumenterer for, at naturens årsagssammenhænge (kausalitet) er menneskeblinde og derfor konstant bryder med menneskets formålsbestemte forsøg på at skabe mening (rationalitet), hvorimod de afslappede naturalister ikke accepterer denne forståelse af naturen som grundlæggende umenneskelig.

En førende streng naturalist er Daniel C. Dennett. Han argumenterer for, at vi må begynde udforskningen af naturen med en accept af naturens radikale umenneskelighed: "In the beginning, there were no reasons; there were only causes. Nothing had purpose, nothing had so much as a function; there was no teleology. The explanation

4. Det er filosoffen John McDowell, der for godt tyve år indførte distinktionen mellem "bald" og "relaxed" naturalisme i sin indflydelsesrige bog Mind and World (Cambridge, MA: Harvard University Press 1994). Som han forklarer i en senere artikel, "Two Sorts of Naturalism", Mind, Value, and Reality, (Cambridge, MA: Harvard University Press 1998), 167-197 (197) var distinktionen et forsøg på at bane vejen til "an acceptable naturalism". McDowells kritik af den ubesmykkede eller strenge naturalismes krav om et ufortyndet naturvidenskabeligt naturbegreb er, som det bliver tydeligt i det efterfølgende, afgørende for debatten om naturalisme i dag. 
for this is simple: There was nothing that had interest". 5 Denne accept medfører, at når det kommer til grundlæggende spørgsmål om naturen og menneskets plads i den, må refleksive discipliner som filosofi og psykologi bøje sig for naturvidenskaberne, selv om dette fra et menneskeligt perspektiv kan forekomme meningsløst:

[W] can and should replace these sacrosanct but brittle traditions with a more naturalistic foundation. It is scary letting go of such honored precepts as the imagined conflict between determinism and freedom, and the false security of a miracle-working Self or Soul to be the place where the buck stops. Philosophical analysis, by itself, is not enough to motivate such a drastic shift in our thinking, even when it is fundamentally correct. ${ }^{6}$

Dennetts argument går kort og godt ud på, at naturalismens opgave må være at stille radikale spørgsmål til vores menneskelige - og fra hans perspektiv alt for menneskelige - naturforståelse. Naturen bryder med vores rationelle og personlige forståelse af den. Mennesket og menneskelige værdier må ikke få lov til at bestemme vores fortolkning. En naturalisme, der ikke respekterer, at de sidste femhundrede års naturvidenskabelige udvikling fra et teleologisk til et kausalt naturbegreb har været ét langt opgør med betændte normer, kulturelle fordomme og rationalistiske forklaringer, er en naturalisme, der ikke lever op til sit navn. Denne kausale udrensning af meningsgivende formål og rationelle forklaringer i vores grundlæggende forståelse af naturen sikrer, at vores videre forsøg på at forstå den menneskelige tilværelse i naturen ikke farves af antropocentriske illusioner eller filosofiske idiosynkrasier.

Den afslappede naturalisme er opstået som en kritik af dette naturbegreb. Dette negative udgangspunkt er blevet beskrevet tydeligt af filosoffen T.M. Scanlon:

This idea, that our ontological commitments should be restricted to things in the physical world of particles and planets that is described by science may strike many as a sensible naturalism. But it is an idea we should not accept. Science is a way of understanding the natural world. Its conclusions represent our best understanding of what that world contains and what happens in it. Accepting science as a way of understanding the natural world entails rejecting claims about witches

5. Daniel C. Dennett, Consciousness Explained (Boston, Mass.: Little, Brown and Company 1991), 173.

6. Daniel C. Dennett, Freedom Evolves (New York: Viking Penguin 2003), 306. For en teoretisk udfordrende diskussion af forholdet mellem filosofisk analyse og empirisk forskning, se David Papineau, "The Poverty of Analysis", Proceedings of the Aristotelian Society Supplementary Volume, LXXXII (2009), 1-30. 
and spirits. But accepting a scientific view of the natural world does not mean accepting that the only meaningful statements with determinate truth values are statements about the natural world, or that things in the natural world are the only things that we should be ontologically committed to 7 .

Scanlon er ikke selv hverken streng eller afslappet naturalist, men bruger sin kritik af den strenge naturalismes ontologiske imperialisme til at argumentere for en streng etisk rationalisme, der insisterer på "en logisk kløft" mellem etik og naturforklaringer (Scanlon 2014, 38-42). Som det vil blive tydeligt i de næste to afsnit, er netop dette brud mellem etik og natur afgørende for min egen naturalistiske position og for, hvilken rolle jeg tillægger naturalisme i udarbejdelsen af en kristen etik.

De afslappede naturalister deler Scanlons kritik af den strenge naturalistiske naturforståelse, men vil ikke vide af nogen kløft eller noget brud mellem umenneskelig natur og menneskelig etik. Tværtimod anser de det for deres filosofiske opgave at vise, at naturen i sig selv er væsentlig mere menneskelig, end den fremstilles hos både Scanlon og de strenge naturalister. David MacArthur, en indflydelsesrig fortaler for den afslappede naturalisme, argumenterer for dette synspunkt i forsøget på at vise, at den strenge naturalismes radikale kriterier for naturalisme er uacceptable. Man kan - og skal - være naturalist på mere liberale vilkår. Opgaven for en filosofisk naturalist består ikke i blindt at følge i naturvidenskabens kolde fodspor, men tværtimod at argumentere imod naturvidenskabernes umenneskeliggørelse af naturen:

The world we inhabit is not a bare physical-cum-biological world, but a social and cultural world involving human actions, languages, institutions, and various forms of art, architecture, and artefacts. The significances, meanings, and values (ethical, social, aesthetic etc.) of such things are essential aspects of our experience of the world. ${ }^{8}$

Naturen, som vi mennesker erfarer og forestiller os den, er ikke den meningsløse natur, som Dennett og hans strenge naturalistiske følgesvende fortæller os, at vi rent faktisk lever i og med. Ved at insi-

7. T.M. Scanlon, Being Realistic About Reasons (Oxford: Oxford University Press 2014), 17-18.

8. David MacArthur, "Naturalizing the Human or Humanizing Nature: Science, Nature and the Supernatural.” Erkenntnis, vol. 61, nr. 1 (2004), 29-51 (36). Tanken om en delvis genfortryllelse af naturen efter den naturvidenskabelige umenneskeliggørelse har MacArthur fundet hos sin lærermester McDowell, der argumenterer for en forståelse af nature som "partially enchanted, but without lapsing into prescientific superstition or a rampant platonism” (McDowell 1994, 85). 
stere på prioriteten af den menneskelige erfaring - og delvise teleologiske genfortryllelse - af naturen forsøger MacArthur at vise, at de strenge naturalister arbejder med "preconceived ideas or ideological constructions of metaphysics into which, it is supposed, science must fit". ${ }^{9}$ MacArthur og de afslappede naturalister vil "menneskeliggøre naturen" (MacArthur 2004) for at skabe plads til den menneskelige erfaring og rationalitet i vores grundlæggende forståelse af naturen. Hvis vi skal være i stand til at leve et godt liv som naturalister, bliver vi - ifølge de afslappede naturalister - nødt til at lade den menneskelige erfaring slå sprækker i den golde naturvidenskabelige forståelse, så farver, kærlighed, lykke og andre fundamentale menneskelige træk får lov til at sive ned i det naturalistiske grundvand. Den afslappede naturalistiske verden er med andre ord ikke radikalt anderledes end vores før-videnskabelige forestillinger om den.

Hvis det - som Scanlon gør opmærksom på - kan være svært at se, hvordan vi kan bygge en menneskelig tilværelse på baggrund af de strenge naturalisters umenneskelige forståelse af naturen som meningsløs, så er det på den anden side ligeså vanskeligt at se, hvordan de afslappede naturalisters menneskelige naturforståelse kan karakteriseres som naturalisme. Hvor den strenge naturalismes naturbegreb forekommer for goldt for et menneskeliv, synes den afslappede naturalismes naturbegreb for menneskeligt blomstrende. På trods af deres drastisk forskellige naturbegreber deler de to former for naturalisme dog den grundlæggende opfattelse, at vores eksistentielle grundvand er naturalistisk. Vores liv er bestemt af naturens liv i den forstand, at vores følelser, tanker og handlinger næres og formes af naturens udvikling og rytmer. Der er ingen unaturlige guder eller immaterielle ånder, og fordi vi lever af det naturalistiske grundvand, er vi nødt til at skabe vores eksistens efter naturalismens forskrifter. Det vil sige, at begge former for naturalisme arbejder med en ubrudt forbindelse mellem natur og etik. Etikken skal med andre ord udformes på et naturalistisk grundlag.

I det næste afsnit vil jeg forsøge at vise, at forskellen på - og de respektive problemer forbundet med - de to former for naturalisme netop bliver tydelige, hvis vi ser på, hvordan de hver især forsøger at pumpe dette grundvand op til den eksistentielle overflade i form af etiske forestillinger om, hvordan vi kan live et godt liv på naturalistiske forudsætninger.

9. David MacArthur, "Taking the Human Sciences Seriously", Mario de Caro og David MacArthur (2010), 123-141(132). 


\section{Naturalistiske forestillinger om et godt liv}

Der er mange vanskelige teoretiske spørgsmål på spil i diskussionen om de to former for naturalisme, og de udspringer næsten alle af det vedholdende filosofiske spørgsmål om forholdet mellem krop (hjerne) og sind (bevidsthed). I det sidste årti er denne teoretiske diskussion dog blevet overtaget af en anden og mere praktisk diskussion om naturalismens betydning for vores forståelse af den menneskelige tilværelse. Denne diskussion er del af en mere generel drejning i filosofien i samme periode, der leder væk fra det tyvende århundredes besættelse af teoretiske og abstrakte problemer og frem mod - eller rettere tilbage til - en mere pragmatisk forståelse af filosofiens grundlæggende opgave. ${ }^{10}$ I stedet for at sidde alene i et hjørne og nørkle med verdensfjerne teorier skal filosoffer give sig i kast med konkrete problemer og frem for alt være i stand til at skelne spørgsmål, der har betydning for levende mennesker, fra spørgsmål, der ikke er væsentlige for vores liv.

Det er ikke et tilfælde, at mange af fortalerne for en afslappet form for naturalisme samtidig er betydningsfulde pionerer i denne pragmatiske drejning i filosofien. ${ }^{11}$ Pragmatisme og afslappet naturalisme synes at være to aspekter af den samme filosofi. Ligesom den store pragmatiker John Dewey, der for godt hundrede år siden skrev om knudrede filosofiske problemer, at "[w] e don't solve them: we get over them", ${ }^{12}$ deler de nye pragmatikere den afslappede naturalismes utålmodighed med dunkle teoretiske spørgsmål om menneskets plads i naturen ( $\mathrm{fx}$ frihed og nødvendighed, subjektivitet og objektivitet, rationalitet og kausalitet, etik og natur). Fra et pragmatisk synspunkt er det håbløse spørgsmål, der ikke vedkommer andre end teologer, strenge naturalister og verdensfjerne filosoffer. Vi kan ikke svare på dem, så vi skal i stedet bruge vores energi på de praktiske udfordringer, der forhindrer os i at leve et godt liv.

Pragmatismens ihærdige forsøg på at genetablere det gode livs filosofi bestyrker den afslappede naturalismes agenda om at finde en naturalisme, der viser, at naturen er meningsfuld og i bund og grund

10. Solide introduktioner til denne betydningsfulde drejning i filosofien: Michael Bacon, Pragmatism: An Introduction (Cambridge: Polity Press 2012); Richard Bernstein, The Pragmatic Turn (Cambridge: Polity Press 2010). For vanskeligere, men også mere teoretisk udfordrende diskussioner, se Cheryl Misak (red.), New Pragmatist (Oxford: Oxford University Press 2007); Huw Price (red.), Expressivism, Pragmatism, and Representationalism (Cambridge: Cambridge University Press 2013).

11. Hilary Putnam, John McDowell, Huw Price og Philip Kitcher er her blandt de mest indflydelsesrige.

12. John Dewey, The Influence of Darwin on Philosophy and Other Essays (New York: Henry Holt and Company 1910), 19. 
god for mennesket. Jeg startede med at skrive, at jeg ikke opfatter naturalisme som et muligt fravalg. Jeg anser det naturvidenskabelige fortolkningsgrundlag som afgørende - og på mange måder velgørende - for vores forestilling om naturen og menneskets plads i den. Jeg er af den opfattelse, at vores eksistentielle grundvand er og altid har været naturalistisk, hvilket betyder, at jeg anser de sidste fem hundrede års naturvidenskabelige udforskning af dette grundvand for at være altafgørende for vores filosofiske, teologiske og eksistentielle spørgsmål i dag. Jeg er derfor grundlæggende naturalist. Samtidig mener jeg dog ikke, at vi udelukkende på et naturalistisk grundlag kan forstå, hvad det vil sige at leve som menneske i naturen. Den menneskelige erfaring af naturen er uomgængelig i vores forståelse af mennesket og den menneskelige tilværelse. Det kan derfor forekomme naturligt, at jeg ville anse den afslappede naturalisme for den mest tiltrækkende mulighed. Det er ikke tilfældet.

Jeg finder den metodiske sammenblanding af naturvidenskab og menneskelig erfaring i den afslappede form for naturalisme problematisk, eftersom jeg mener, at den er indspundet i pragmatiske forestillinger om et godt liv, der fortegner vores forståelse af både menneske og natur. Mennesket lever sit liv i naturen som en del af naturen. At anerkende naturen som bestemmende for et menneskes liv er som sagt naturalismens grundlæggende pointe. Ved at følge den afslappede naturalismes argument for at lade menneskelig erfaring, værdier og normer sive ned i den naturalistiske grundforståelse og lade denne forståelse danne grundlag for en pragmatisk forestilling om et godt liv mister vi blikket for den kompleksitet, der kendetegner menneskets liv i naturen. Naturen er ikke blot menneskets eksistensgrundlag, men også et problem for mennesket. På trods af de imponerende naturvidenskabelige landvindinger brydes vores forståelse og forsøg på meningsdannelse stadig mod naturens på samme tid rå og vidunderlige uforståelighed. Hvorfor er jeg født? Hvad er meningen med en uhelbredelig hjernesvulst? Hvorfra kommer min kærlighed? Det er uden tvivl radikale spørgsmål, som kun få naturalister - strenge såvel som afslappede - vover et svar på, men de udspringer nu engang af den natur, i og med hvilken vi lever vores liv.

Jeg mener derfor, at de strenge naturalisters radikale forståelse af naturens umenneskelighed er at foretrække fremfor de afslappede naturalisters pragmatiske forsøg på at menneskeliggøre en natur, hvis konkrete udfordringer konstant bryder menneskets forsøg på forståelse og mening. Naturen bestemmer vores liv på trods af vores forståelse af godt og ondt, smukt og grimt, passende og upassende, og denne naturens grundlæggende uforståelighed er en nødvendig baggrund for vores forestillinger om et godt liv. Min strenge naturalistiske afvisning af menneskelig erfaring og menneskelige værdier i 
forståelsen af naturen betyder dog ikke, at jeg underkender den menneskelige erfarings betydning for vores forsøg på at forstå og leve som mennesker. Den menneskelige erfaring af naturens umenneskelighed er tværtimod altafgørende i vores forståelse af, hvad det vil sige at være menneske.

Jeg kan derfor ikke følge de strenge naturalisters skarpskårne forestillinger om et godt liv eller deres aggressive felttog mod traditionel filosofisk etik. De insisterer på, at vores forestillinger om et godt liv og vores etiske forsøg på at sikre et sådant må konstrueres udelukkende på det grundlag af kausal umenneskelighed, som deres naturalisme argumenterer for. ${ }^{13}$ Hvis vi vil forstå forskellen på godt og ondt, nytter det ikke noget - ifølge disse strenge naturalister - at sætte sig mageligt til rette i den filosofiske lænestol og genoverveje arven fra Aristoteles, Spinoza og Hume. Vi skal derimod op af lænestolen og ind i laboratoriet eller ud $\mathrm{i}$ junglen for at undersøge informationsprocesser, hjernens etiske plasticitet, evolutionær udviklingsdynamik eller rygkradsende altruisme blandt bonobo-aber. Før-videnskabelig menneskelig erfaring og rationalitet er som nævnt blot et flakkende skær på overfladen af evolutionens kraftfulde dyb, der ender med at gøre mere skade end gavn i forsøget på at nå frem til en solid etisk forståelse af et godt liv.

Problemet med en etik bygget direkte på et strengt naturalistisk grundlag er netop, at den er umenneskelig. I forsøget på en gennemført naturalisme vil en sådan etik ikke lade sig forstyrre af det faktum, at vores forestillinger om et godt liv er bestemt af andet og mere end den etisk ubønhørlige natur, som naturvidenskaberne blotlægger. Frihed og subjektivitet kan have vekslende status i den teoretiske diskussion om naturalisme, men de er afgørende faktorer i menneskers forestilling om et godt liv, og etiske overvejelser, der ikke tager disse faktorer alvorligt, ender med at konstruere en etik, man som følende og tænkende menneske har meget svært ved at forene med forestillinger om et godt liv.

Hvor de strenge naturalister forsøger at indrette deres forestillinger om et godt liv efter deres naturforståelse, er det omvendte tilfældet med de afslappede naturalister. Deres naturforståelse bestemmes af deres forestillinger om et godt liv. Det betyder, at de heller ikke skelner skarpt mellem etik og naturforståelse. Ligesom med deres natur-

13. Se fx William D. Casebeer, Natural Ethical Facts: Evolution, Connectionism, and Moral Cognition (Cambridge, Mass.: The MIT Press 2003); Daniel C. Dennett, Freedom Evolves (New York: Penguin 2003); Michael S. Gazzaniga, The Ethical Brain (New York: Dana Press 2005); Patricia S. Churchland, Braintrust: What Neuroscience Tells Us about Morality (Princeton: Princeton University Press 2011); Frans de Waal, The Bonobo and the Atheist: In Search of Humanism Among the Primates (New York: W.W. Norton \& Company 2013). 
forståelse indretter de forståelsen af etik efter deres forestillinger om et godt liv. Det er her, deres pragmatiske opfattelse af natur og menneske sætter sig igennem. ${ }^{14}$ Etik er en naturlig del af det at leve som menneske. "It comes unbidden. It comes with living", som Simon Blackburn skriver (Blackburn 1998, 2). Det er svært at være uenig i, at etik er en naturlig del af det at leve som menneske. Problemet er, at denne etikkens naturlighed føres over i etikkens opgave. Etikkens fordring skal - som det fremgår - spejle sig i den konkrete verden, så dens krav til mennesket ikke bliver urimelige. Den skal bygge på, hvad der kan lade sig gøre på baggrund af det mest velovervejede og fornuftige syn på naturen og mennesket. Den afslappede naturalisme, der ligger til grund for en sådan etik, sikrer, at hverken metafysiske teorier, teologi eller radikale etiske fordringer spiller en rolle i disse overvejelser. Det er tværtimod vores opgave at finde frem til den bedste etik på de pragmatiske betingelser, som livet nu engang fører med sig, uden at denne pragmatisme bliver forstyrret af naturens umenneskelige meningsløshed eller religiøse illusioner om en anden mening under (eller over) livets pragmatiske overflade. Spørgsmålet om sandhed, teoretisk såvel som praktisk, kommer hverken fra naturvidenskab eller religion, men er - som pragmatikeren William James så berømt skrev - noget, der sker med en idé, når den efterprøves på det konkrete liv. ${ }^{15}$ En pragmatisk etik er med andre ord en bekræftelse af en særlig forestilling om et godt liv, hvor et menneskes etiske opgave er at finde den mest fornuftige måde at leve med sin erfaring af blindt raseri, håbløs kærlighed, social uretfærdighed, meningsløs død og andre af livets radikale udfordringer. Vi skal naturligvis acceptere det faktum, at radikale udfordringer er en del af livet, men den etiske opgave består netop i at lade denne accept styre vores forestillinger om et godt liv sikkert udenom de radikale svar, som religion og streng naturalisme giver på sådanne udfordringer.

14. Se fx Allan Gibbard, Wise Choices, Apt Feelings: A Theory of Normative Judgment (Oxford: Oxford University Press 1990); Simon Blackburn, Ruling Passion. A Theory of Practical Reasoning (Oxford: Oxford University Press 1998); Hilary Putnam, Ethics Without Ontology (Cambridge, Mass.: Harvard University Press 2004); Richard Rorty, Philosophy as Cultural Politics: Philosophical Papers (Cambridge: Cambridge University Press 2007); Philip Kitcher, The Ethical Project (Cambridge, Mass.: Harvard University Press 2011). Mens Rorty, Putnam og Kitcher er fuldblods pragmatikere, så er Gibbard og Blackburn mere tøvende med deres pragmatiske konklusioner. Kendetegnende for dem alle er deres afslappede naturalisme, opgør med religion og en utålmodighed med streng rationalistisk etik.

15. William James, Pragmatism: A New Name for Some Old Ways of Thinking (London: Longmans, Green \& Co 1907), 201 (kursiv i orginalen):"The truth of an idea is not a stagnant property inherent in it. Truth happens to an idea. It becomes true, it is made true by events. Its verity is in fact an event, a process: the process namely of its verifying itself, its very-fication. Its validity is the process of its valid-ation". 
Det er i spørgsmålet om livets radikale udfordringer til vores forestillinger om et godt liv, at jeg finder den afslappede naturalismes pragmatiske løsning uholdbar.

Min kritik af henholdsvis streng og afslappet naturalisme betyder, at selvom jeg som naturalist bifalder den strenge naturalismes naturbegreb og den grundlæggende naturalistiske pointe, at vores eksistens er formet og bestemt af det naturalistiske grundvand, så mener jeg ikke, at vi som mennesker kan leve af dette grundvand. I modsætning til både de strenge og de afslappede naturalisters forsøg på at etablere en forbindelse mellem det naturalistiske grundvand og vores forestillinger om et godt liv, arbejder jeg med et radikalt brud mellem denne naturalistiske understrøm og etikken.

I det sidste afsnit vil jeg forsøge at argumentere for, at livets radikalitet betyder, at alene en etik, der bryder med vores forestillinger om et godt liv, er i stand til at muliggøre, at vi rent faktisk kan leve et godt liv. Det er netop på baggrund af den strenge naturalismes radikale udfordring, at en kristen etik viser sin styrke.

\section{Den kristne etiks (ud)fordring til et godt liv}

Man kan godt leve et godt liv på baggrund af en velovervejet kombination af afslappet naturalisme og pragmatiske forestillinger om et godt liv. Den pragmatiske forestilling om et godt liv er uden tvivl en god og fornuftig måde at indrette sit liv på. Livet er for mange mennesker domineret af pragmatiske spørgsmål om, hvordan vi bedst håndterer dagligdagens store og små udfordringer i forbindelse med arbejde, kærlighed, børn, venner, madlavning, fritidsinteresser og alle de andre ting, der gør et liv behageligt og meningsfuldt.

Det løsningsorienterede fokus på tilværelsens håndgribelige udfordringer i en pragmatisk etik risikerer dog at fjerne opmærksomheden fra et grundlæggende etisk spørgsmål. Arbejder en pragmatisk etik for, at alle kan leve et godt liv? Dette spørgsmål blotlægger to udfordringer til en pragmatisk etik. Den første er etikkens universale fordring. Etik er ikke blot et spørgsmål om, hvordan man lever et godt liv, men også en radikal fordring om, at alle skal leve et godt liv. Den anden er frihedens krav. Det vanskelige ved etiske overvejelser består $\mathrm{i}$ at forene den radikale fordring om et godt liv for alle med hvert enkelt menneskes krav om frihed til at forestille sig, hvad et godt liv er for hende eller ham. Det pragmatiske svar på disse grundlæggende etiske problemer er det samme som den afslappede naturalismes løsning på grundlæggende naturalistiske problemer: hvis vi blot overtager den pragmatiske forestilling om et godt liv, så indser 
vi, at det er problemer, vi ikke kan løse og derfor bør komme ud over. Pragmatikeren vil overbevise os om, at etikkens universale fordring og kravet om frihedens individuelle udtryk kun kan forenes, hvis vi er villige til at gå på kompromis med radikaliteten. Vi kan - ifølge pragmatikeren - ikke bygge en etik, der kræver os til ansvar for alle menneskers mulighed for at leve et godt liv, samtidig med at den insisterer på den individuelle frihed til at forestille sig, hvad et godt liv er. En sådan etik er ikke mulig i denne verden, men er en etisk metafysiks ideologiske konstruktion på linje med de strenge naturalisters metafysiske fordrejning af naturen.

Pragmatismen overser - eller vælger at se bort fra - det tilværelsens faktum, at ligesom udfordringen ved at leve som menneske i og med en natur, der ikke bekymrer sig om vores menneskelige følelser, tanker og drømme, ikke bliver mindre radikal ved, at vi insisterer på naturens menneskelighed, så bliver udfordringen ved at forene frihed og etisk fordring heller ikke mindre radikal ved, at vi insisterer på frihedens pragmatiske begrænsninger. Der gives intet pragmatisk meningsfuldt svar på naturens frygtelige paradoks, at et barn bliver uhelbredeligt sygt af kræft, ligesom der ingen pragmatisk løsning er på det konkrete etiske paradoks, at tusinder dør af fedme, mens endnu flere sulter ihjel.

Den amerikanske poet Christian Wiman, som jeg citerer i begyndelsen, har i de sidste otte år levet med en radikal udfordring af sine forestillinger om et godt liv. Han er midt i fyrrene og lider af en yderst sjælden og uhelbredelig blodkræft. Han har tilbragt måneder i hospitalssenge, forsøgt adskillige rygmarvstransplantationer og strejfet døden op til flere gange. Hans seneste bog, My Bright Abyss, er et på samme tid kynisk og forhåbningsfuldt poetisk forsøg på at udtrykke hans kamp med sygdommens meningsløshed og den måde, hvorpå den har fået ham til at genoverveje den kristendom, som han ellers har brugt det meste af sit voksne liv på at komme væk fra. Bogen er bemærkelsesværdig, eftersom den forsøger at kommunikere et håb ved at fremhæve håbløsheden. Poesi er afgørende for dette forsøg, eftersom den formår at give et udtryk til den ubestemmelige radikalitet, som Wiman oplever i sin erfaring af biologisk meningsløshed. Bogen er bygget op af aforismer og digte (Wimans egne såvel som andre poeters), hvis kristne og biologiske udtryk brydes og forenes over sygdommens stigninger og fald. Her er to på hinanden følgende aforismer, der er adskilte ved deres erfaringsbrud, men forenet $i$ et grundlæggende paradoks:

The terrible thing - it could perhaps be a glorious thing, always the ill are meant to see it as such, are reproached if they don't (carpe fucking 
diem) - the terrible thing about feeling the inevitability of your own early death is the way it colors every single scene. At some friends' house I am moved by the beauty and antics of their two-year-old daughter - moved, and then saddened to think of the daughter that D. and I might have, for whom my death will be some deep, lightless hole that for the rest of her life she will walk around, grief the very ground of her being. What is this world that we are so at odds with, this beauty by which we are so wounded, and into which God has so utterly gone?

Into which, rather than from which: in a grain of grammar, a world of hope

(Wiman 2013, 145-146; kursiv i originalen).

Det filosofisk interessante ligger i Wimans brud mellem den første aforismes beskrivelse af et øjebliks følelsesmæssige kompleksitet bestående af glæde, skam, sorg og et udmattet spørgsmål om mening og så det korte svar i den efterfølgende aforisme, der med et radikalt grammatisk skifte skærer igennem den følelsesmæssige forvirring og lader et håb bryde frem i hjertet af - og ikke på trods af eller i modsætning til - meningsløshed. Meningsløshedens udfordring af vores forestillinger er håbets styrke. I den konkrete umenneskelighed afslører håbet et krav til vores forestilling om, hvad det vil sige at leve som menneske. Menneskelighed er ikke et faktum ved hverken mennesket eller verden, men et håb, der gør os opmærksomme på frihedens radikale ansvar for menneskelighed.

Denne frihedens radikalitet er kernen i den kristne etik, som jeg her vil argumentere for. Den filosofiske styrke i denne etik bliver netop tydelig på baggrund af den strenge naturalismes meningsløse naturbegreb. Det er en etik, der ikke accepterer den pragmatiske afvisning af radikale svar på spørgsmålet om mennesket og naturen, fordi den insisterer på at fastholde den menneskelige tilværelses radikale udfordringer til vores forestillinger om et godt liv. Det er en kristen etik, fordi den bygger på kristendommens radikale svar på spørgsmålet om forholdet mellem etik og frihed i disse forestillinger. Radikaliteten i det kristne svar er tydeligst i buddet om fjendekærlighed, og dette bud danner den hårde kerne i mit argument. ${ }^{16}$

Mange er af den opfattelse, at buddet om at elske sin fjende er et umenneskeligt bud. Og eftersom etik forsøger at forstå menne-

16. Denne argumentation trækker kraftigt på Kant og Kierkegaard. Særligt på Kants grundlæggende arbejde med forholdet mellem natur, forestilling og frihed og Kierkegaards arbejde med frihed, forestilling og kærlighed. Begge tænkere er kritikere af forestillinger om et godt liv og udfolder deres kritik på baggrund af den kristne etiks radikalitet. Af hensyn til artiklens omfang ekspliciterer jeg ikke her min fortolkning af de to tænkere. 
skers forhold til hinanden og udstikke normative retningslinjer for menneskeligt samliv, kan det - både umiddelbart og ved nærmere eftertanke - virke forkert at føre etiske overvejelser på grundlag af et umenneskeligt bud. Kristen etik bliver derfor i etiske diskussioner ofte anset som et uinteressant levn fra en tid, der i sin religiøse iver endnu ikke havde opdaget det naturalistiske grundvand, der nærer nutidige etiske problemstillinger. Det er ikke blot sekulariserede filosoffers manglende forståelse for kristendommens rige etiske traditioner, der er skyld i sådanne afvisninger. Også kristne etikere bærer et ansvar for den kristne etiks manglende gennemslagskraft i den aktuelle etiske debat. Når den kristne etik knyttes uløseligt sammen med en bestemt gudsforståelse eller et udtalt skriftsyn, taber den sin filosofiske styrke i en tid, hvor gud og skrift ikke længere umiddelbart kan danne baggrund for etiske overvejelser. Det betyder ikke, at dogmatik ikke er afgørende for forståelsen af kristen etik, men blot, at hvis de dogmatiske overvejelser om etik og de etiske overvejelser om dogmatik skal have betydning i dag, må sådanne overvejelser acceptere, at det naturalistiske grundvand former vores tids etiske klima. Denne accept behøver ikke at betyde, at en kristen etik skal tilpasse sig en naturaliseret etik eller lempe på sin grundlæggende radikalitet. Den skal derimod arbejde på at argumentere for sin særegne etiske radikalitet på en sådan måde, at de naturalistiske udfordringer får den fornødne opmærksomhed. Det er omridset af en sådan argumentation, jeg nu vil forsøge at tegne op.

Det umenneskelige i fjendekærlighed må udgøre kernen i enhver form for kristen etik. Forsøg på at menneskeliggøre den kristne etik underminerer både den kristne etiks kristne særpræg og dens filosofiske styrke. Buddet rummer to grundlæggende elementer: et deskriptivt og et normativt. Det deskriptive element består i den nøgterne konstatering, at mennesker har en udtalt hang til at udvikle fjendskab. Uanset hvor fornuftigt vi vælger at indrette vores samfund, eller hvor varsomme og forstående vi er i mødet med andre mennesker, så udspringer jalousi, usikkerhed, vrede, skam og had ligeså spontant af medmenneskeligt samvær, som ømhed, tryghed, glæde, stolthed og kærlighed gør det. Faktum er, at fjendskab eksisterer. Det normative element i fjendekærlighed bygger på og tager ved lære af dette faktum. Uanset hvor stærkt vi etisk fordømmer fjendskabets umenneskelige udtryk, så er fjendskab dybt rodfæstet i hjertet af vores menneskelighed. Vi er med andre ord etisk hjælpeløse i mødet med dette eksistensens radikale faktum. Denne accept af det umenneskelige i vores menneskelighed er fjendekærlighedens normative styrke. Vores hang til fjendskabets umenneskelige udtryk afslører brudflader i vores forestillinger om, hvad det vil sige at leve et godt liv. Fjendskab er dybt indlejret $\mathrm{i}$ vores normative horisont og præger vores forestilling 
om godt og ondt på trods af os selv. Fjendskab viser sig ikke blot i det udtalte fjendskab, men også i vores tiltag i form af pragmatiske kompromisser, overvejelsens tøven, fornuftige løsninger og refleksionens indesluttede kredsen om sig selv. En del af fjendekærlighedens normative radikalitet ligger i dens kritik af vores normative forestillinger.

Denne normativitetskritik hænger uløseligt sammen med det vanskelige forhold mellem frihed og etik i vores forestillinger om et godt liv. Den grundlæggende hang til fjendskab kommer netop til udtryk i forestillinger om et godt liv. Hvert enkelt menneske har mere eller mindre artikulerede forestillinger om et godt liv, hvis eksistentielle udtryk kan være vanskelige at forene med det andet menneskes forestillinger. Og fordi friheden til at forestille sig et godt liv er afgørende for etiske forsøg på at skabe mulighed for, at alle kan leve et godt liv, kan min forestilling om et godt liv ikke danne grundlag for en etik. Accepten af fjendskabets radikale udfordring af vores forestillinger om et godt liv kan derfor alene føre til et ligeså radikalt normativt krav om kærlighedens udfordring af vores forestillinger om, hvad der er menneskeligt og umenneskeligt. At elske sin fjende er ikke umenneskeligt, men en udfordring af og en fordring til vores forestilling om menneskelighed. Denne (ud)fordring er på samme tid en kritik af vores forestilling om et godt liv.

Fjendskab bevæger sig på grunden af mine forestillinger om et godt liv, uanset hvor fornuftige eller forstående disse forestillinger er. På grund af frihedens radikale individualitet er jeg ikke i stand til at forstå det andet menneskes forestilling om et godt liv, og denne mangel på forståelse betyder, at jeg ikke formår at forene mine forestillinger med det andet menneskes forestillinger. Frihedens radikale individualitet står imellem os. Mine forestillinger om et godt liv med det andet menneske er allerede et udtryk for et grundlæggende fjendskab, eftersom det er mine forestillinger. Vrede, had og misundelse er som nævnt blot en artikulation af den grundlæggende hang til fjendskab, der ligger i forestillinger om et godt liv. Men samtidig er det frihedens radikalitet, der er i stand til at forene os på trods af vores forestillinger. Som jeg skrev i begyndelsen, er det de færreste mennesker, der kan forestille sig et godt liv uden det andet menneske. Et liv uden intimitet, spontan glæde i det andet menneskes ansigt, tillid, begær, tryghed og kærlighed er ikke, hvad de fleste mennesker betragter som et godt liv. Problemet er, at mit liv med andre mennesker er vanskeligt, fordi vi hver især har vores egen forestilling om, hvad et godt liv indebærer. Når - eller rettere hvis - jeg indser utilstrækkeligheden i mine forestillinger om et godt liv med den anden, bliver det tydeligt, at min frihed til at forestille mig et godt liv medfører et radikalt ansvar for at elske den anden på trods af min forestilling om, hvad det vil sige at leve et godt liv. Ligesom min grundlæggende hang til fjend- 
skab er en radikal udfordring af min forestilling om, hvad det vil sige at eksistere og leve som menneske, på samme måde er mit grundlæggende behov for kærlighed en radikal udfordring af min forestilling om godt og ondt, muligt og umuligt, smukt og grimt, fornuftigt og ufornuftigt, passende og upassende. Kærlighed er et håb, vi ikke kan forestille os, og en opgave, vi ikke kan afslutte. En kristen etik er en kritik af vores forestillinger om et godt liv, fordi vores forestillinger uvægerligt går på kompromis med etikkens universelle fordring og frihedens individuelle krav i sit forsøg på skabe et godt liv. Det er en etik, der forener universalitetens blindhed og frihedens krav om synlighed i et bud, der - som Kant skriver - fastholder en etisk fordring uden anskuelse og uden indbildningskraft i sin kamp for en uforståelig menneskelighed og - som Kierkegaard insisterer - samtidig gør det til en pligt at elske det konkrete menneske, vi ser. ${ }^{17}$

Den kristne etik, jeg her har forsøgt at tegne et omrids af, er en radikal etik. Den er kompromisløs i sin nedbrydelse af vores forståelse af godt og ondt og kompromisløs i sit krav om et godt liv for alle mennesker. Den arbejder på baggrund af den strenge naturalismes argument for naturens umenneskelighed. Ligesom naturens radikale uforståelighed konstant udfordrer vores naturforestillinger, insisterer denne etik på, at dens radikale fordring om uforståelig kærlighed udfordrer vores forestillinger om kærlighed. Vi kan hverken finde ro i naturen eller etikken. Det er denne konstante eksistentielle uro, der gør vores forestillinger om et godt liv slørede, usammenhængende og modsætningsfyldte. En kritik af vores forestillinger om et godt liv betyder ikke, at vi ikke skal bruge disse forestillinger i vores beslutninger og valg. Det kommer helt af sig selv. En af etikkens opgaver er derimod at vise, hvordan vores forestillinger om et godt liv risikerer at udelukke eller skade det andet menneske, der er forudsætningen for disse forestillinger. Naturens og etikkens radikale udfordring gør mine forestillinger slørede og mine valg skrøbelige, men denne angstfulde uro er en uløselig del af det at eksistere som menneske. En kristen etik bruger denne uro til at vise, hvordan mening bryder med oplevelsen af meningsløshed. Det er dog ikke en beroligende mening, der viser sig i dette brud med meningsløshed, men - som Christian Wiman skriver - et skrøbeligt håb om mening: "I should never pray to be at peace in my belief. I should pray only that my anxiety be given peaceful outlets, that I might be a means to a peace that I myself do not feel" (Wiman 2013, 108).

17. Se fx, Immanuel Kant, Kritik der praktischen Vernunft, Kant's Gesammelte Schriften, Band 5 (Berlin: Verlag von Georg Reimer 1913), 56, 121-122; Søren Kierkegaard, Kjerlighedens Gjerninger, Søren Kierkegaards Skrifter, Bind 9 (København: Gad 2004), 155-174. 
Denne ubestemmelige uro i og ved vores menneskelighed er blevet mere tydelig efter den naturalistiske forvisning af Gud fra vores forestillinger om et godt liv. Spørgsmålet om Gud er på mange måder spørgsmålet om, hvad det vil sige at være menneske. Det betyder, at svaret på spørgsmålet om vores menneskelighed er et håb, vi alene finder realiseret i Gud. Men Gud er ikke længere til stede i forgrunden af vores forestillinger. Fraværet af Gud har ført til en større opmærksomhed på de konkrete problemer, der udgør vores eksistentielle forgrund. Det er denne opmærksomhed, som den aktuelle sammenblanding af pragmatisme og afslappet naturalisme udnytter i sin insisteren på at samle vores filosofiske kræfter i forsøget på at løse de håndgribelige problemer, der kommer til syne i forgrunden af vores liv som mennesker. På den måde er spørgsmålet om menneskelighed blevet mere konkret, mens det på samme tid er blevet mere ubestemmeligt. Den voksende opmærksomhed på politiske, kulturelle og sociale forskelle mellem menneskelige forestillinger om et godt liv har medført en øget bevidsthed om den menneskelige friheds ubestemmelige karakter. Dette er unægtelig en god udvikling. Problemet ved at fokusere på konkrete spørgsmål om et godt liv er dog, at det åbne spørgsmål om menneskelighed risikerer at lukke sig og blive til en udelukkende pragmatisk undersøgelse af, hvad det vil sige at leve som menneske. Menneskelighed ændrer med andre ord karakter, idet den går fra at være et spørgsmål til at blive et svar. Løsningen på etiske problemer bliver, at vi skal gøre vores tilværelse som mennesker mere menneskelig (dvs. rationel, demokratisk, ansvarlig, fri, forstående, tolerant osv.). Denne løsningsorienterede forståelse af etik arbejder bevidst uden om konfrontationen med det radikale spørgsmål om menneskelighed, der rører sig i grunden af vores konkrete eksistentielle bekymringer. Dette er et problem, eftersom vi derved risikerer at overse, at friheden til at blive menneskelig er skrøbelig netop i kraft af sin ubestemmelighed. Menneskelighed er ikke et svar, men alene et håb. Og det er ganske rigtigt, at vi ikke længere kan finde et umiddelbart svar på dette håb i Gud, eftersom Gud er forsvundet fra vores forestillinger om et godt liv. Men som Wiman gør opmærksom på, betyder det ikke, at håbet er forsvundet sammen med vores forestillinger om Gud. Tværtimod er det på baggrund af den voksende forståelse af frihedens ubestemmelighed muligt at anse etik som et radikalt ansvar for at bruge denne frihed til at arbejde for et håb om menneskelighed $\mathrm{i}$ en verden, hvorind i - "into which" Gud er forsvundet. 